\title{
MIR200B wt Allele
}

National Cancer Institute

\section{Source}

National Cancer Institute. MIR200B wt Allele. NCI Thesaurus. Code C82156.

Human MIR200B wild-type allele is located in the vicinity of 1 p36.33 and is 104 bases in length. This allele, which encodes the MIR200B pre-miRNA, plays a role in the regulation of gene expression. Alteration in the expression of this gene is associated with the development of hepatocellular carcinoma, cholangiocarcinoma and breast cancer. 